University of Nebraska - Lincoln

DigitalCommons@University of Nebraska - Lincoln

Estimated Flood Discharges and Map of Flood-Inundated Areas for Omaha Creek, near Homer, Nebraska, 2005

Benjamin J. Dietsch

USGS, bdietsch@usgs.gov

Richard C. Wilson

Kellan R. Strauch

Follow this and additional works at: https://digitalcommons.unl.edu/usgspubs

Part of the Earth Sciences Commons

Dietsch, Benjamin J.; Wilson, Richard C.; and Strauch, Kellan R., "Estimated Flood Discharges and Map of Flood-Inundated Areas for Omaha Creek, near Homer, Nebraska, 2005" (2008). Publications of the US Geological Survey. 12.

https://digitalcommons.unl.edu/usgspubs/12

This Article is brought to you for free and open access by the US Geological Survey at DigitalCommons@University of Nebraska - Lincoln. It has been accepted for inclusion in Publications of the US Geological Survey by an authorized administrator of DigitalCommons@University of Nebraska - Lincoln. 
Prepared in cooperation with the Village of Homer, Nebraska, and the Papio-Missouri River Natural Resources District

\section{Estimated Flood Discharges and Map of Flood-Inundated Areas for Omaha Creek, near Homer, Nebraska, 2005}

Scientific Investigations Report 2008-5107 



\section{Estimated Flood Discharges and Map of Flood-Inundated Areas for Omaha Creek, near Homer, Nebraska, 2005}

By Benjamin J. Dietsch, Richard C. Wilson, and Kellan R. Strauch

Prepared in cooperation with the Village of Homer, Nebraska, and the

Papio-Missouri River Natural Resources District

Scientific Investigations Report 2008-5107 


\section{U.S. Department of the Interior DIRK KEMPTHORNE, Secretary}

\section{U.S. Geological Survey \\ Mark D. Myers, Director}

\section{U.S. Geological Survey, Reston, Virginia: 2008}

For product and ordering information:

World Wide Web: http://www.usgs.gov/pubprod

Telephone: 1-888-ASK-USGS

For more information on the USGS — the Federal source for science about the Earth, its natural and living resources, natural hazards, and the environment:

World Wide Web: http://www.usgs.gov

Telephone: 1-888-ASK-USGS

Any use of trade, product, or firm names is for descriptive purposes only and does not imply endorsement by the U.S. Government.

Although this report is in the public domain, permission must be secured from the individual copyright owners to reproduce any copyrighted materials contained within this report.

Suggested citation:

Dietsch, B.J., Wilson, R.C., and Strauch, K.R., 2008, Estimated flood-inundation map for Omaha Creek, near Homer, Nebraska, 2005: USGS Scientific Investigations Report 2008-5107, 10 p. 


\section{Contents}

Abstract
Introduction
Purpose and Scope
Description of the Study Area
Delineation of Areas Inundated by a Flood with 1-Percent Annual Probability
Estimated Flood Discharges and Map of Flood-Inundated Areas
Summary and Conclusions
References Cited

\section{Figures}

1-2. Maps showing:

1. Location of Omaha Creek Basin and the study area in Dakota and Thurston Counties, northeastern Nebraska...................................................................................................

2. Location of U.S. Geological Survey streamflow-gaging station, survey cross sections,

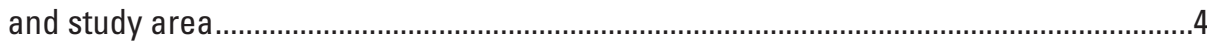

3. Comparison of streambed elevations at locations surveyed in 1993 and 2005 along Omaha Creek at Homer, Nebraska .............................................................................

4. Frequency of selected flooding events for Omaha Creek near Homer, Nebraska, determined by log-Pearson Type III analysis for the systematic record (1946-2004) and

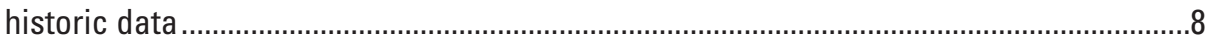

5. Areas at risk for inundation by the 1-percent annual probability flood (100-year flood) on Omaha Creek, at Homer, Nebraska.

\section{Tables}

1. Summary of flood frequency for Omaha Creek at Homer, Nebraska, determined by logPearson Type III analysis of the systematic record (1946-2004) and historical data .......6

2. Water-surface elevation for estimated discharges and flood-recurrence intervals at U.S. Geological Survey streamflow-gaging station on Omaha Creek near Homer, Nebraska (06601000) 


\section{Conversion Factors, Abbreviations, and Datum}

\begin{tabular}{lll}
\hline \multicolumn{1}{c}{ Multiply } & By & \multicolumn{1}{c}{ To obtain } \\
\hline cubic foot per second $\left(\mathrm{ft}^{3} / \mathrm{s}\right)$ & 0.02832 & cubic meter per second $\left(\mathrm{m}^{3} / \mathrm{s}\right)$ \\
inch (in) & 2.54 & centimeter $(\mathrm{cm})$ \\
foot (ft) & 0.3048 & meter $(\mathrm{m})$ \\
mile (mi) & 1.609 & kilometer $(\mathrm{km})$ \\
square mile $\left(\mathrm{mi}^{2}\right)$ & 2.590 & square kilometer $\left(\mathrm{km}^{2}\right)$ \\
cubic foot $\left(\mathrm{ft}^{3}\right)$ & 28.32 & cubic decimeter $\left(\mathrm{dm}^{3}\right)$ \\
cubic foot $\left(\mathrm{ft}^{3}\right)$ & 0.02832 & cubic meter $\left(\mathrm{m}^{3}\right)$ \\
foot per mile $(\mathrm{ft} / \mathrm{mi})$ & 0.1894 & meter per kilometer $(\mathrm{m} / \mathrm{km})$ \\
foot per second $(\mathrm{ft} / \mathrm{s})$ & 0.3048 & meter per second $(\mathrm{m} / \mathrm{s})$ \\
\hline
\end{tabular}

Vertical coordinate information is referenced to the National Geodetic Vertical Datum of 1929 (NGVD 29). 


\title{
Estimated Flood Discharges and Map of Flood-Inundated Areas for Omaha Creek Near Homer, Nebraska, 2005
}

\author{
By Benjamin J. Dietsch, Richard C. Wilson, and Kellan R. Strauch
}

\section{Abstract}

Repeated flooding of Omaha Creek has caused damage in the Village of Homer. Long-term degradation and bridge scouring have changed substantially the channel characteristics of Omaha Creek. Flood-plain managers, planners, homeowners, and others rely on maps to identify areas at risk of being inundated.

To identify areas at risk for inundation by a flood having a 1-percent annual probability, maps were created using topographic data and water-surface elevations resulting from hydrologic and hydraulic analyses. The hydrologic analysis for the Omaha Creek study area was performed using historical peak flows obtained from the U.S. Geological Survey streamflow gage (station number 06601000). Flood frequency and magnitude were estimated using the PEAKFQ Log-Pearson Type III analysis software. The U.S. Army Corps of Engineers' Hydrologic Engineering Center River Analysis System, version 3.1.3, software was used to simulate the water-surface elevation for flood events. The calibrated model was used to compute streamflow-gage stages and inundation elevations for the discharges corresponding to floods of selected probabilities. Results of the hydrologic and hydraulic analyses indicated that flood inundation elevations are substantially lower than from a previous study.

\section{Introduction}

Flooding of Omaha Creek has caused damage in the Village of Homer, Nebraska, since the 1920's. To mitigate flood damages financially and to manage development within the regulatory floodplain, the village entered into the National Flood Insurance Program administrated by the Federal Emergency Management Agency (Federal Emergency Management Agency, 1983). This program provides maps for identifying areas at risk for flooding and helps flood-plain managers, planners, homeowners, stakeholders, and others make decisions about areas that are at risk for flooding. The Flood Insurance Study for the Village of Homer in Dakota County, Nebraska, was issued by Federal Emergency Management Agency
(FEMA) in 1983 (Federal Emergency Management Agency, 1983) and was revised in 1996 (Federal Emergency Management Agency,1996). Since the 1996 revision, additional streamflow data have been collected to aid in estimating the frequency of large floods. In addition, the Omaha Creek channel has undergone long-term general degradation and localized scour near bridges that may have affected the hydraulic properties of the channel near Homer since it was last surveyed in 1993. As channel characteristics of Omaha Creek continue to change, the Village of Homer and the Papio-Missouri River Natural Resources District entered into a cooperative agreement with the U.S. Geological Survey (USGS) to study the effects of these changes on the areas at risk for flooding around Homer, Nebraska.

\section{Purpose and Scope}

The purpose of this report is to estimate flood discharges to update the 1996 FEMA Flood Insurance Study for the Village of Homer, Nebraska, (FEMA, 1996) and the map of the area inundated by the flood having a 1-percent annual probability using additional streamflow data and recent (2005) topographic data (Nebraska Department of Natural Resources, written commun., 2005).

Topics addressed for this report included peak-flow analyses of records from the USGS streamflow-gaging station on Omaha Creek at Homer, Nebraska, (station number 06601000; fig. 2); collection of topographic and channelgeometry data; hydraulic analysis of Omaha Creek using the U.S. Army Corps of Engineers' (USACE) Hydrologic Engineering Center River Analysis System (HEC-RAS) computer software (U.S. Army Corps of Engineers, 2001); and mapping flood-inundation areas that correspond to the flood having a 1-percent annual probability by comparing hydraulic results with topographic data.

The geographical scope of this report was limited to areas near Homer, Nebraska, where cross sections from previous studies were available. This includes the reach of Omaha Creek from Elma Road, located about 1 mile (mi) east of Homer, to Grant Road, located approximately $1.5 \mathrm{mi}$ south of Homer. 


\section{Description of the Study Area}

Omaha Creek is a northeasterly flowing tributary of the Missouri River and is located in Dakota and Thurston Counties in northeastern Nebraska (fig. 1). The total drainage area is 175 square miles $\left(\mathrm{mi}^{2}\right)$ at the gaging station at Homer. Soils in the basin are derived primarily from glacial tills capped with loess (Elder, 1969). The climate of Dakota and Thurston Counties is classified as continental, consisting of a subhumid moisture regime and moderate temperatures. The normal annual rainfall is approximately 26 inches at Sioux City, Iowa (National Weather Service, 2005).

The study area (fig. 2) surrounds the Village of Homer and its extent corresponds to the available hydraulic cross section data; the downstream limit is located about 2 mi upstream (north) from the mouth of Omaha Creek. It is a deeply incised channel that is widening in some parts of the study area and exhibits steep banks, bank failures, and streambed degradation (Rus and others, 2003). The stream channel slope is about 8.5 feet per mile $(\mathrm{ft} / \mathrm{mi})$ through the $4-\mathrm{mi}$ study reach. Bed materials at the site are composed of silty clays. Vegetation along the downstream part of the reach generally is sparse because of steep bank angles and recent bank failures; however, grass, shrubs, and small trees line the upstream areas of the reach.

Extensive straightening and channel modification of streams in the Omaha Creek Basin have occurred since the early 20th century (Nebraska Department of Roads and Irrigation, 1954). These changes in channel alignment may have triggered a degradation response in the lower part of the Omaha Creek Basin, including most of the study area. From 1952 to 1996 , the streambed degraded approximately $2.6 \mathrm{ft}$ at Omaha Creek at Homer, but the migration of this bed elevation change may have been limited by the construction of a rock riffle near the gage in the 1950's (Rus and others, 2003). Field inspections indicate that severe scour has occurred around bridge piers along the study reach.

Flooding has occurred in the Village of Homer since it was incorporated in 1871 (Federal Emergency Management Agency, 1996). Significant flooding occurred in June, 1875; June, 1900; September, 1903; March, 1909; May, 1920; June, 1940; February, 1971; and July, 1996. The most severe documented floods occurred in 1920 and 1940. On May 31, 1920, excessive rainfall occurred, which caused widespread flooding. Newspaper and historical accounts of the 1940 flood describe severe damage to many homes and businesses with water elevations higher than any flood since 1920. The USGS began operating a streamflow-gaging station located on Omaha Creek near Homer (station 06601000) in 1940. The maximum peak flow for the period of record occurred June 4, 1940, at a gage height of $34.50 \mathrm{ft}$ (2005 gage datum) with a discharge of 51,000 cubic feet per second $\left(\mathrm{ft}^{3} / \mathrm{s}\right)$ estimated from indirect measurements. Other significant floods occurred in $1971\left(18,100 \mathrm{ft}^{3} / \mathrm{s}\right)$ and $1996\left(21,500 \mathrm{ft}^{3} / \mathrm{s}\right)$.

\section{Hydrologic Analysis}

The hydrologic analysis for the Omaha Creek study area used historical data for peak flows obtained at the stream gage. Historical data for peak flows were available from the instantaneous-discharge records for the USGS streamflowgaging station at Homer (station 06601000) which includes the period of streamflow gage operation from 1946 through 2004, and the estimate of peak discharge in 1940, which was the greatest peak discharge since 1920. Flood frequency and magnitude were estimated using the USGS PEAKFQ log-Pearson Type III analysis software (Flynn and others, 2006). The PEAKFQ software (version 5.0.0) was used for standard log-Pearson Type III analysis as outlined in Bulletin 17B (Interagency Advisory Committee on Water Data, 1982). The systematic-record analysis computed by PEAKFQ utilizes the mean, standard deviation, and skew coefficient of the log-transformed annual peak flow series, or systematic record, to fit a log-Pearson distribution function to the data. The frequency curve derived from the systematic-record analysis is an initial estimate of the Bulletin 17B frequency curve. Additional analyses are used to adjust the frequency curve for historic data, regional (generalized) skew information, and high and low outliers; historic data, or flood information outside that contained in the systematic records, can be used to extend the period of analysis. The analytical techniques to adjust for historic data are described in Bulletin 17B (Interagency Advisory Committee on Water Data, 1982) and implemented in PEAKFQ. PEAKFQ provides a routine for weighting the computed skew coefficient with a regionalized skew coefficient. Because the skew coefficient computed from historical streamflow data for a station can be sensitive to extreme events, guidance in Bulletin 17B recommends weighting skew coefficients computed for stations with natural streamflow regimes with a generalized skew coefficient computed for an entire region or similar set of sites. For the PEAKFQ analysis for the USGS streamflow-gaging station at Homer (station 06601000), the generalized skew coefficient of -0.539 was used (Soenksen and others, 1999). PEAKFQ also computes outliers, or extremely high and extremely low peak flows in a record, that can disproportionately affect the results of flood frequency analysis. Thresholds for determining outliers are computed based on the sample size (Flynn and others, 2006). Peak streamflows were estimated for floods of the 50-, 20-, 10-, 4-, 2-, 1-, and 0.2-percent annual probabilities.

\section{Hydraulic Analyses}

The U.S. Army Corps of Engineers HEC-RAS, version 3.1.3, software was used to simulate the water-surface elevation for floods (U.S. Army Corps of Engineers, 2001). Simulated water-surface elevations of Omaha Creek within the study reach were calculated by the HEC-RAS hydraulic flow model that requires topographic data, channel and bridge geometry and characteristics, and steady, gradually varied 


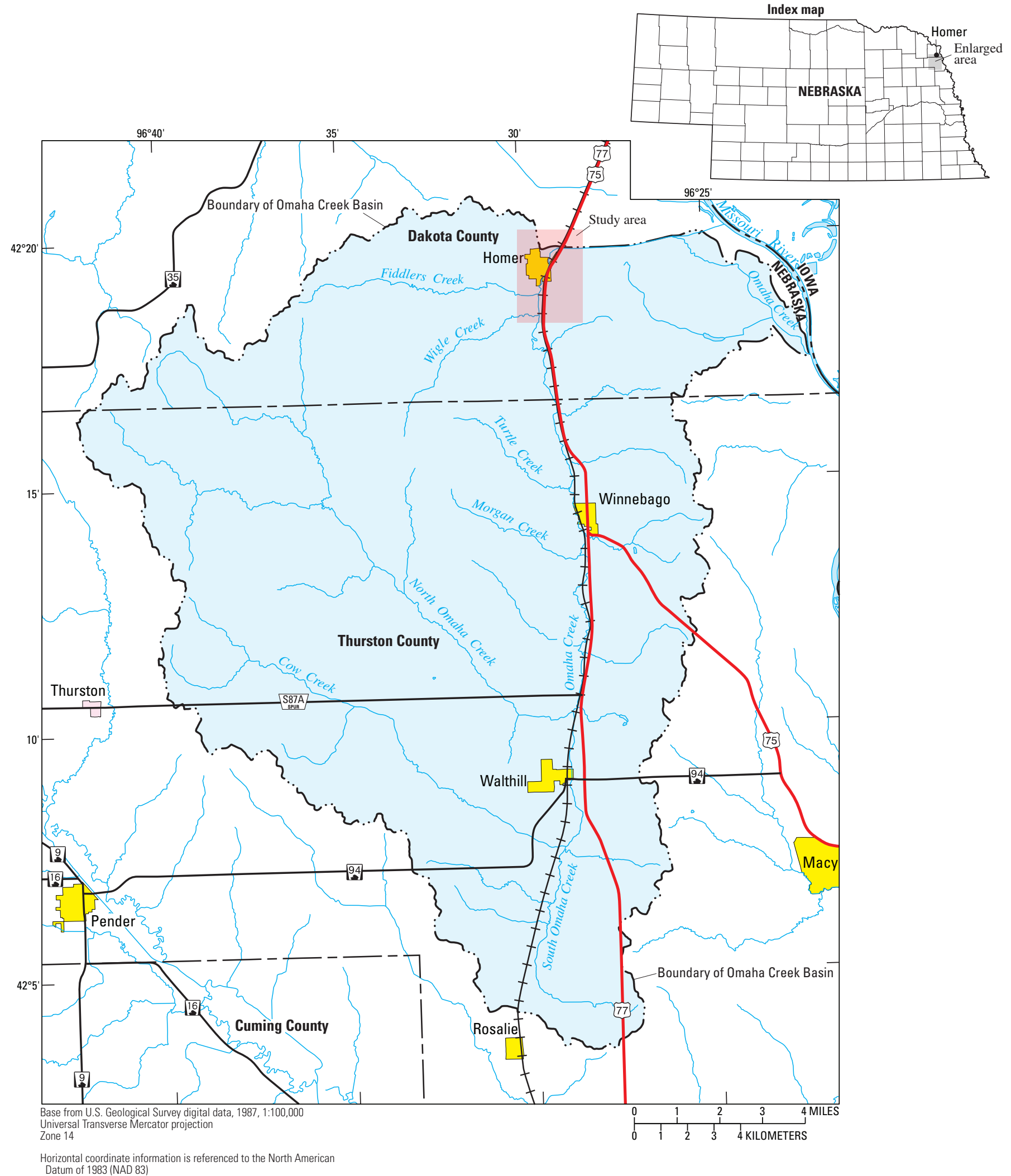

Figure 1. Location of Omaha Creek Basin and the study area in Dakota and Thurston Counties, northeastern Nebraska. 


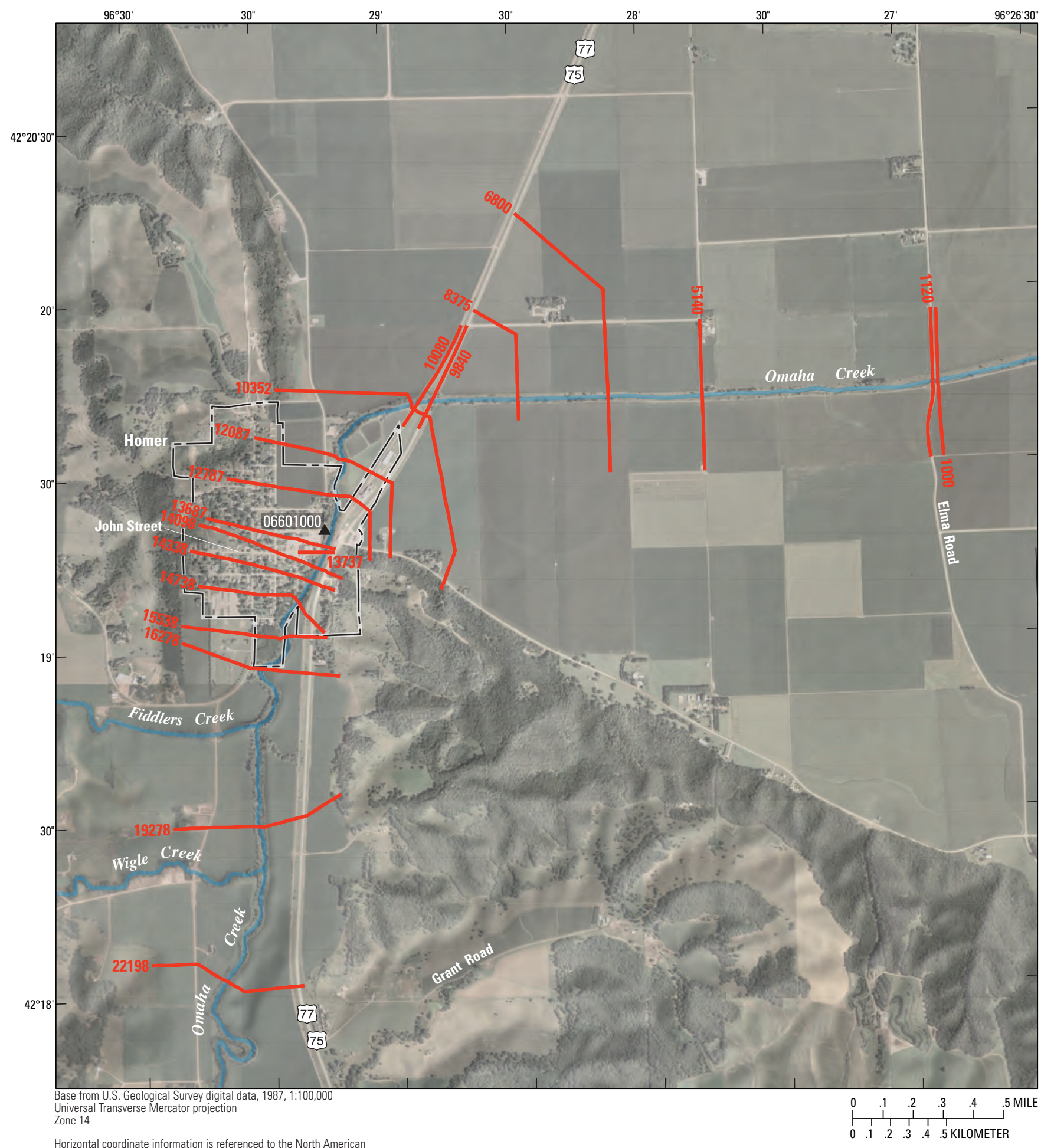

Horizontal coordinate information is referenced to the North American Datum of 1983 (NAD 83)

\section{EXPLANATION}

22198 River station cross section-Number is main channel distance in feet upstream from model original near Elma Road plus 1,000 feet

$06601000 \quad$ U.S. Geological Survey gaging station and number

Figure 2. Location of U.S. Geological Survey streamflow-gaging station, survey cross sections, and study area. 
streamflow as inputs. Energy losses were computed using friction and contraction/expansion calculations.

Topographic data were field surveyed in 1993 and 2005 by the Nebraska Department of Natural Resources (Nebraska Department of Natural Resources, written commun., 2005). Twenty-two river station cross sections were surveyed in the Omaha Creek channel in the study reach. Land-surface elevations of the areas within and adjacent to the channel were surveyed in 1993. In 2005, field surveys were limited to parts of the cross section including and between the tops of stream banks. The cross sections used in the HEC-RAS model were a composite of the topographic points surveyed in 1993 (overbank areas) and in 2005 (channel areas between tops of banks).

Comparison of 1993 and 2005 survey data indicated channel widening throughout the study reach and extensive scouring had occurred near bridges (fig. 3).

Geometric data included hydraulic characteristics of the stream, such as friction coefficients, expansion and contraction ratios, reach distances, and hydraulic properties of structures, such as bridge dimensions. Manning's roughness coefficients were estimated from field observations, aerial photographs, and previous studies (Federal Emergency Management Agency, 1996) using methods described in Barnes (1967) and Arcement and Schneider (1989). Manning's roughness coefficients ranged from 0.036 to 0.050 in the channel, and from 0.065 to 0.175 in areas adjacent to the channel. Bridge geometry was obtained from aerial photographs and previous studies (Federal Emergency Management Agency, 1996).

Steady-flow input data included results of the hydrologic analysis and downstream boundary conditions. Peak discharges estimated from the hydrologic analysis were used as steady-flow input values of streamflow for simulations of the floods. Two downstream boundary-condition scenarios were simulated for the peak discharge with 1-percent annual probability: normal depth was assumed at the downstream boundary; and alternatively the water-surface elevation at the downstream boundary was assumed to be equal to the water-surface elevation of the Missouri River corresponding to its peak discharge with 1-percent annual probability. Energy slope for the normal-depth boundary-condition simulation was assumed to be $0.0006 \mathrm{ft} / \mathrm{ft}$, based on the previous study (Federal Emergency Management Agency, 1996). The results of the simulation using this boundary condition and slope were compared

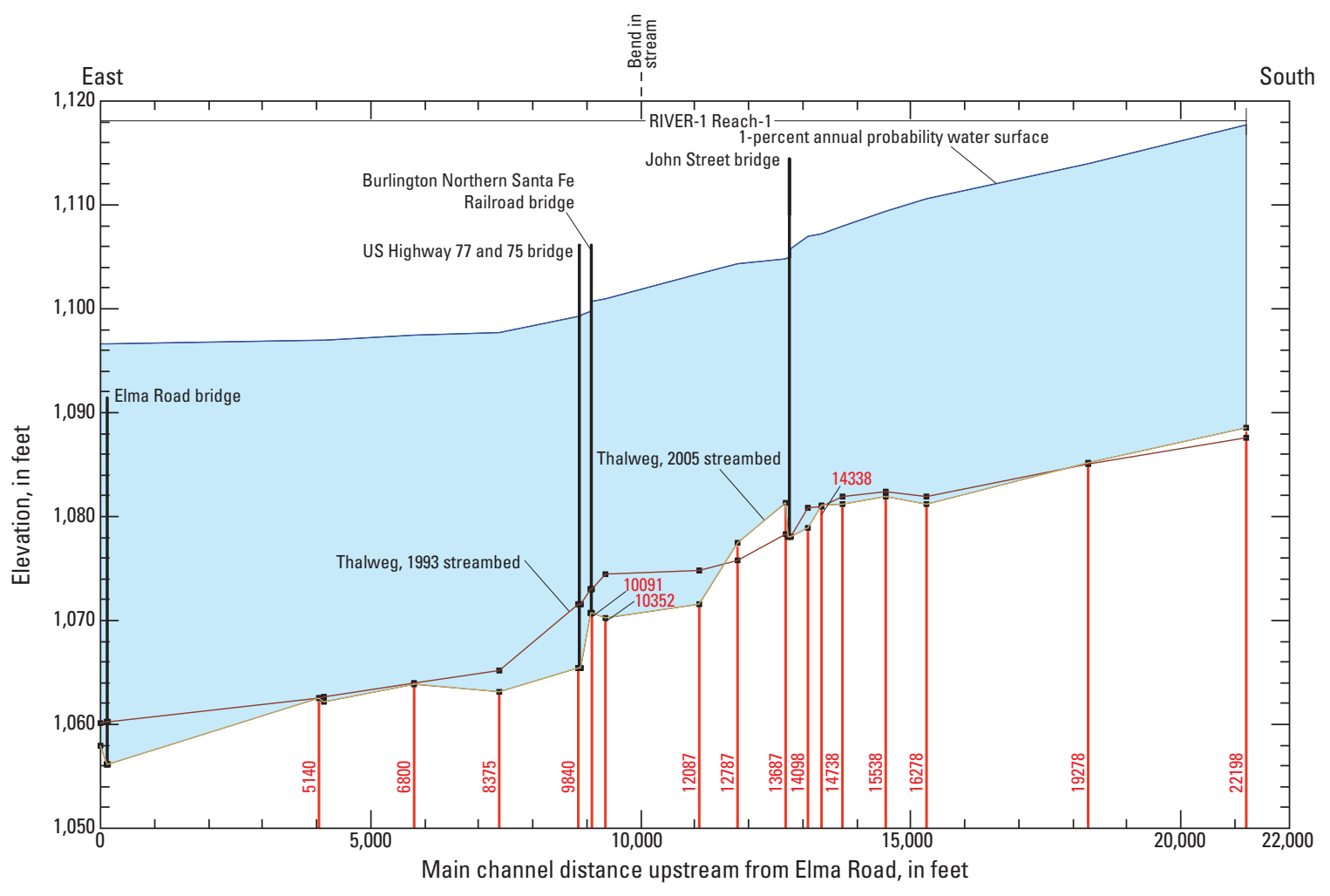

EXPLANATION

River station cross section-Number is main channel distance in feet upstream from model original near Elma Road plus 1,000 feet

Figure 3. Comparison of streambed elevations at locations surveyed in 1993 and 2005 along Omaha Creek at Homer, Nebraska. 
to simulation using the channel slope surveyed in 2005 and the normal depth boundary conditions and were determined to be similar. The downstream water-surface elevation corresponding to the peak discharge of the Missouri River with 1-percent annual chance flood was $1096.6 \mathrm{ft}$ above the National Geodetic Vertical Datum of 1929 (NGVD 29) (Federal Emergency Management Agency, 1996).

The hydraulic model for Omaha Creek was calibrated to the stage and discharge that was measured on August 30, 1993, at the USGS streamflow-gaging station at Homer (station 06601000). The measurement was selected because it was the most recent direct measurement of a discharge near or exceeding the peak flow with 50-percent annual probability. The measured discharge on that date was $3,530 \mathrm{ft}^{3} / \mathrm{s}$ at a stage of $9.06 \mathrm{ft}(1,089.51 \mathrm{ft}$ NGVD 29). The hydraulic model was calibrated by iteratively making small adjustments to Manning's roughness coefficients until the water-surface elevation computed by the model closely agreed with the measured flood discharge and stage values at hydraulic cross section 12787 (fig. 2).

The calibrated model was used to simulate stages and inundation elevations for the discharges with 50-, 20-, 10-, 4-, 2-, 1-, and 0.2-percent annual probabilities, which is the annual probability multiplied by $100(0.5,0.2,0.1,0.04,0.02$, $0.01,0.002)$.

\section{Delineation of Areas Inundated by a Flood with 1-Percent Annual Probability}

The areas at risk for inundation by a flood with1-percent annual probability were mapped using topographic data and water-surface elevations from the hydraulic analyses. A triangulated irregular network (TIN) representation of the three-dimensional land surface was constructed from surveyed cross sections and longitudinal lines (Nebraska Department of Natural Resources, written commun., 2005), and 10-ft interval elevation contours (U.S. Geological Survey, 1976). A watersurface elevation model (as a TIN) was constructed from the results of the hydraulic analyses for a flood with 1-percent annual probability under the condition in which the watersurface elevation at the downstream boundary was assumed to be equal to the water-surface elevation of the Missouri River corresponding to its peak discharge with 1-percent annual probability. The water-surface elevation TIN represents the flood profile for a flood with 1-percent annual probability interpolated linearly between the cross sections used in the hydraulic model. The water-surface elevation TIN was overlaid digitally onto the land-surface TIN, and areas where the estimated water-surface elevation was greater than the landsurface elevation were considered to be at risk for inundation by a flood with a 1-percent annual probability. The outlines of the inundated areas were smoothed to remove unnatural corners and edges. The outline of the areas at risk for inundation was overlaid on high-resolution aerial photography of the study area.

\section{Estimated Flood Discharges and Map of Flood-Inundated Areas}

Peak streamflows were estimated for floods of 50-, 20-, 10-, 4-, 2-, 1-, and 0.2-percent annual probabilities (table 1). The results of the PEAKFQ analysis are shown in table 1 and figure 4. One low outlier and one high outlier were removed from the analysis. The high outlier is the discharge estimated for the flood of 1940. An annual peak of $230 \mathrm{ft}^{3} / \mathrm{s}$ in 1970 was treated as a low outlier.

The calibrated hydraulic model was used to simulate stages and inundation elevations for the discharges with 50-, 20-, 10-, 4-, 2-, 1-, and 0.2-percent annual probabilities. Near the stream gage at Homer, the simulated stage for the discharge with 1-percent annual probability was $24.4 \mathrm{ft}$ (1104.8 ft, NGVD 29), which was derived by interpolation between hydraulic cross sections 12787 and 13687 . The results of these analyses are shown in table 2 and figure 4.

Results of the hydraulic analysis indicated that flood inundation elevations are substantially lower than elevations published in the previous study (Federal Emergency Management Agency, 1996). The most important reason for these differences is the set of lower flood discharges resulting from the hydrologic analysis completed for this study. In addition, channel cross-section area has increased because of degradation and channel widening. At river station cross section 10352 (fig. 2) located upstream from the highway bridge, the flood inundation elevation was $3.7 \mathrm{ft}$ lower than that in the previous study. At river station cross section 13768 located upstream from the bridge on the road entering the Homer from the east,

Table 1. Summary of flood frequency for Omaha Creek at Homer, Nebraska, determined by log-Pearson Type III analysis of the systematic record (1946-2004) and historical data.

\begin{tabular}{cccc} 
[-, no published value available] & \multicolumn{3}{c}{$\begin{array}{c}\text { Estimated peak } \\
\text { flow for 1993 }\end{array}$} \\
$\begin{array}{c}\text { Recurrence in- } \\
\text { terval, in years }\end{array}$ & Annual chance & $\begin{array}{c}\text { Estimated peak } \\
\text { flow, in cubic } \\
\text { feet per second } \\
\text { flood insurance } \\
\text { study }{ }^{\prime} \text {, in cubic } \\
\text { feet per second }\end{array}$ \\
\hline 2 & 0.5 & 3,630 & - \\
5 & .2 & 7,050 & - \\
10 & .1 & 9,710 & 10,800 \\
25 & .04 & 13,400 & - \\
50 & .02 & 16,330 & 21,600 \\
100 & .01 & 19,370 & 27,600 \\
500 & .002 & 26,840 & 45,700 \\
\hline
\end{tabular}

${ }^{1}$ Determined using the systematic record from 1946 to 1981 and historical data as published in Federal Emergency Management Agency (1996). 
Table 2. Water-surface elevation for estimated discharges and flood-recurrence intervals at U.S. Geological Survey streamflowgaging station on Omaha Creek near Homer, Nebraska (station 06601000).

$\left[\mathrm{ft}^{3} / \mathrm{s}\right.$, cubic feet per second, NGVD 29, National Geodetic Vertical Datum of 1929]

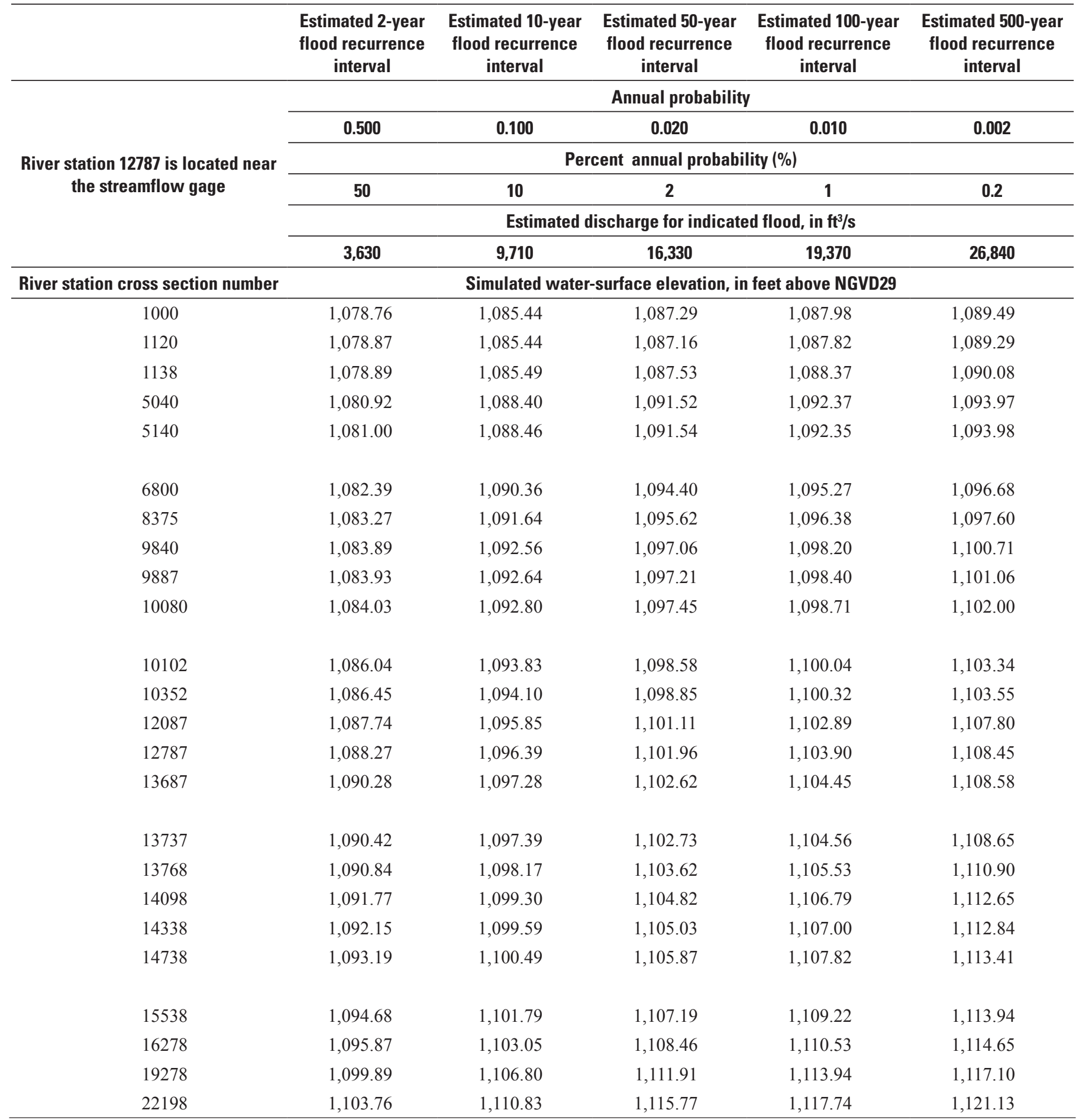


Omaha Creek at Homer, Nebraska (Station 06601000)

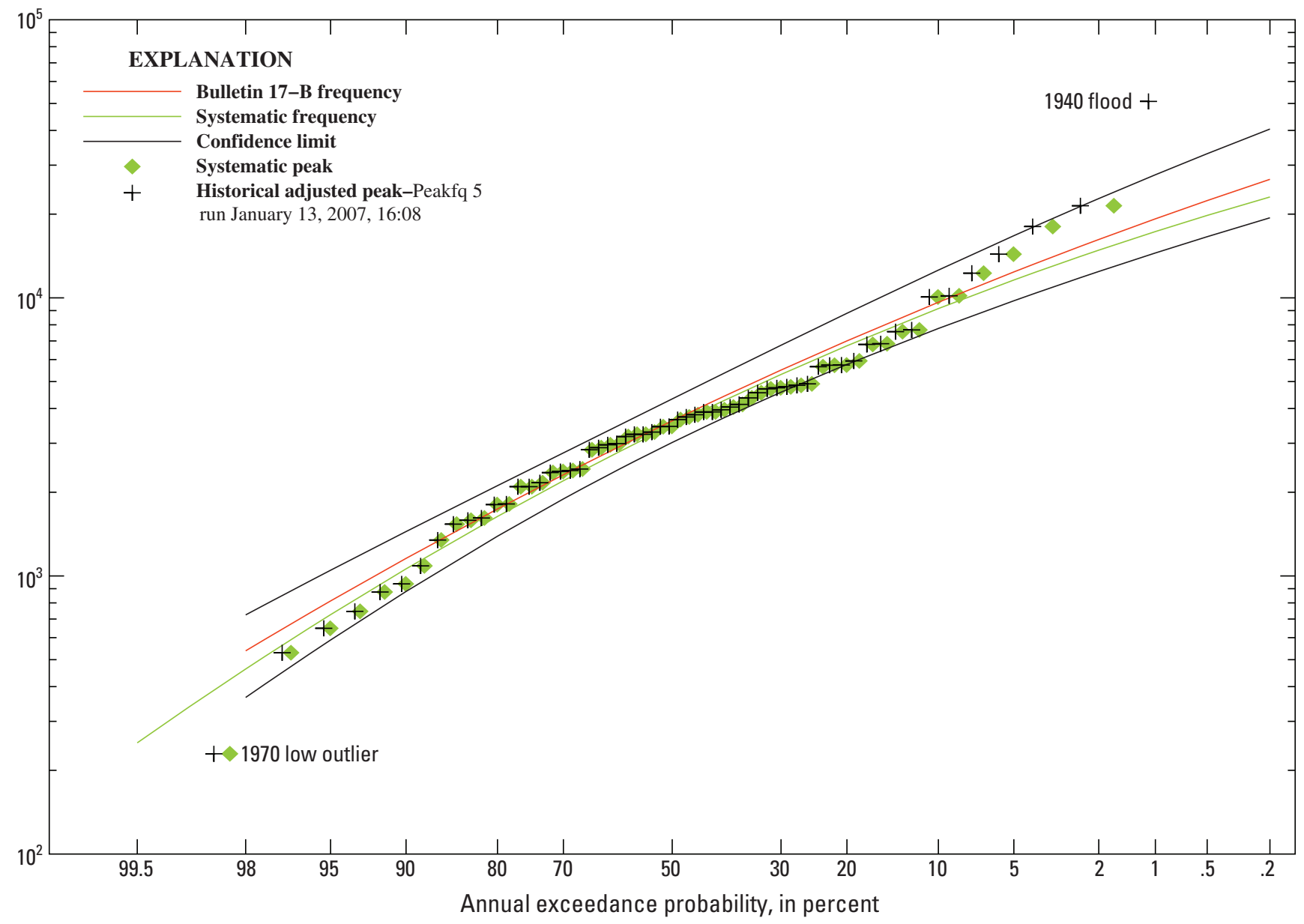

Figure 4. Frequency of selected flooding events for Omaha Creek near Homer, Nebraska, determined by log-Pearson Type III analysis for the systematic record (1946-2004) and historic data.

the flood inundation elevation was $8.2 \mathrm{ft}$ lower than that in the previous study.

The final-flood inundation map for the 1-percent annual probability flood is shown in figure 5 .

\section{Summary and Conclusions}

A map of the areas at risk for inundation by a flood with 1-percent annual probability was produced for the study area by the U.S. Geological Survey in cooperation with the PapioMissouri Natural Resources District and the Village of Homer, Nebraska. The map allows resources at risk of being inundated along Omaha Creek at Homer, Nebraska, to be identified.

The hydrologic analysis for the Omaha Creek study area was performed using historical data for peak flows recorded at the USGS streamflow-gaging station at Homer (station 06601000). Flood discharges were estimated for events with annual probabilities ranging from 0.5 to 0.002 . The U.S. Army Corps of Engineers Hydrologic Engineering Center's River Analysis System (HEC-RAS) version 3.1.3 software was used to simulate the water-surface elevation for selected flood discharges. The calibrated model was used to compute stages and flood-inundation elevations for the selected discharges. The areas at risk for inundation by a flood with 1-percent annual probability were mapped using topographic data and water-surface elevations resulting from the hydraulic analyses.

Results of the hydraulic analysis indicated that flood inundation elevations are substantially lower than elevations published in a previous study. The most important reason for these differences is the set of lower flood discharges resulting from the hydrologic analysis completed for this study. 


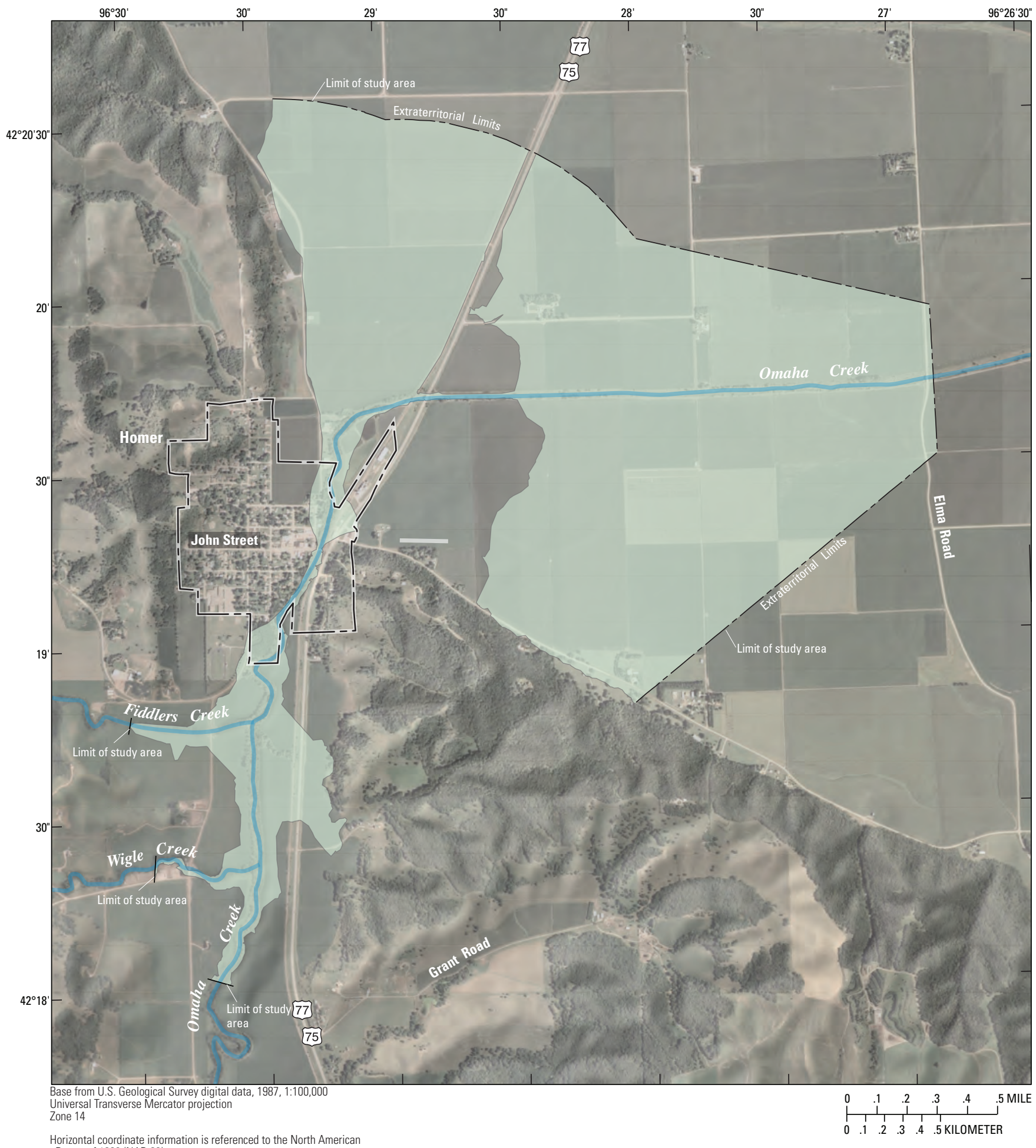

Dorth American Datum of 1983 (NAD 83)

\section{EXPLANATION}

Estimated 100-year floodplain

Figure 5. Areas at risk for inundation by the 1-percent annual probability flood (100-year flood) on Omaha Creek, at Homer, Nebraska. 


\section{References Cited}

Arcement, G.J., Jr., and Schneider, V.R., 1989, Guide for selecting Manning's roughness coefficients for natural channels and floodplains: U.S. Geological Survey Water-Supply Paper 2339, 38 p.

Barnes, H.H., Jr., 1967, Roughness characteristics of natural channels: U.S. Geological Survey Water-Supply Paper 1849, $213 \mathrm{p}$.

Elder, J.A., 1969, Soils of Nebraska: University of NebraskaLincoln, Institute of Agriculture and Natural Resources, Conservation and Survey Division, Resource Report No. 2 , $60 \mathrm{p}$.

Federal Emergency Management Agency, 1983, Flood insurance study, Village of Homer, Dakota County, Nebraska: Washington, D.C., Federal Emergency Management Agency, $15 \mathrm{p}$.

Federal Emergency Management Agency, 1996, Flood insurance study, Village of Homer, Dakota County, Nebraska: Washington, D.C., Federal Emergency Management Agency, $15 \mathrm{p}$.

Flynn, K.M., Kirby, W.H., and Hummel, P.R., 2006, User's manual for program PeakFQ, Annual flood frequency analysis using Bulletin 17B guidelines: U.S. Geological Survey Techniques and Methods Book 4, Chapter B4, 42 p.
Interagency Advisory Committee on Water Data, 1982, Guidelines for determining flood flow frequency: Reston, Virginia, U.S. Geological Survey, Office of Water Data Coordination, Bulletin 17-B of the Hydrology Subcommittee, $183 \mathrm{p}$.

National Weather Service, 2005, Sioux City area climatic summary: Sioux City, Iowa, National Weather Service Forecast Office, accessed March 6, 2007 at http://www.crh.noaa.gov/ fsd/climate/archive.php.

Nebraska Department of Roads and Irrigation, 1954, Thirtieth biennial report of the Department of Roads and Irrigation, 1953-1954, volume II: Lincoln, Nebr., Department of Roads and Irrigation, $801 \mathrm{p}$.

Rus, D.L., Dietsch, B.J., and Simon, Andrew, 2003, Streambed adjustment and channel widening in eastern Nebraska: U.S. Geological Survey Water-Resources Investigations Report 03-4003, 63 p.

Soenksen, P.J., Miller, L.D., Sharpe, J.B., and Watton, J.R., 1999, Peak-flow frequency relations and evaluation of the peak-flow gaging network in Nebraska: U.S. Geological Survey Water-Resources Investigations Report 99-4032, 47 p., 3 appendixes.

U.S. Army Corps of Engineers, 2001, HEC-RAS, River analysis system, user's manual, version 3.0: Davis, Calif., U.S. Army Corps of Engineers Hydrologic Engineering Center.

U.S. Geological Survey, 1976, Homer quadrangle, Nebraska: U.S. Geological Survey Topographic Quadrangle Map, scale 1:24,000. 
Publishing support provided by:

Rolla Publishing Service Center

For more information concerning this publication, contact:

Director, USGS Nebraska Water Science Center

5231 South 19 Street

Lincoln, NE 68512

(402) 328-4100

Or visit the Nebraska Water Science Center Web site at: http://ne.water.usgs.gov 


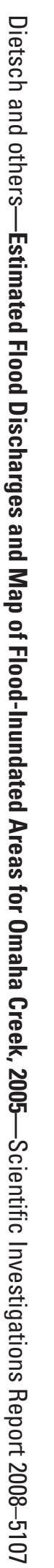

8 Printed on recycled paper 